\title{
SENGKETA PENGAJUAN BANDING TERHADAP PENETAPAN NILAI KEPABEAN DALAM EKSPOR- IMPOR
}

(Analisis Putusan Mahkamah Agung Nomor : Put/52674/PP/M.XVIIA/19/2014 )

\author{
Iwan Kurniawan
}

Fakultas Hukum, Universitas Krisnadwipayana

iwankurniawan33@yahoo.com

\begin{tabular}{|c|c|c|}
\hline Naskah diterima: & Revisi: & Naskah disetujui: \\
$21 / 07 / 2019$ & $25 / 08 / 2019$ & $16 / 09 / 2019$ \\
\hline
\end{tabular}

\begin{abstract}
Abstrak
Dilakukan penulisan ini adalah perihal sengketa penetapan nilai pabean dalam ekspor impor. Importir yang tidak setuju atas penetapan tarif dan/atau nilai pabean oleh pihak pabean sehingga mengakibatkan tambah bayar bea masuk dan pajak, dalam rangka impor diberi kesempatan oleh undang-undang untuk mengajukan keberatan. Atas penetapan Pejabat Pabean dalam rangka pemeriksaan pabean tidak dapat dilakukan kepada pihak manapun, kecuali hanya kepada Direktur Jenderal Bea dan Cukai. Selanjutnya dalam hal keberatannya ditolak importir dapat mengajukan banding ke Pengadilan Pajak. Undang-undang Kepabeanan dengan jelas telah mengatur mekanisme keberatan dan banding dalam pasal 93 sampai dengan pasal 95. Demikian juga penegasan mengenai penerapan Undang-undang Kepabeanan atas segala sesuatu yang berkaitan dengan penyelesaian kewajiban pabean atas barang impor atau ekspor, termasuk pengajuan keberatan, sebagaimana diatur dalam pasal 6 Undang-undang Kepabeanan. Pada prinsipnya Keputusan Pengadilan Pajak bersifat final dan mempunyai kekuatan hukum tetap, tidak bisa dilakukan gugatan kepengadilan umum, peradilan tatausaha negara, atau badan peradilan lain. Pihak yang bersengketa yang tidak puas atas putusan Pengadilan Pajak masih dimungkinkan untuk melakukan upaya hukum lain berupa upaya hukum luar biasa yaitu mengajukan peninjauan kembali atas putusan Pengadilan Pajak ke Mahkamah Agung. Penelitian ini menggunakan penelitian yuridis normatif dengan pendekatan invetarisasi hukum positif. Sumber data yang digunakan dalam penelitian ini berupa data sekunder pengumpulan kepustakaan. Penelitian ini menggunakan analisis kualitatif dengan proses pemikiran deduktif. Dalam variable Penetapan Nilai Pabean Bea dan Cukai. Hasil penelitian ini menjelaskan bahwa variable Sengketa Terhadap Penetapan Nilai Pabean sangat berpengaruh terhadap total penerimaan Negara.
\end{abstract}

Kata kunci: Keberatan, Banding, Peninjauan Kembali

\begin{abstract}
This writing is done about the dispute over customs value is import export. Importers who do not agree on customs tariff and / or value determination by the customs authorities so as to increase the import duty and tax, in the framework of import are given the opportunity by law to submit objections. The determination of Customs Offcials in the framework of customs inspection cannot be carried out any party,except only to the Director General of Customs and Excise. Furthermore, if the objection is rejected, the importer may submit an
\end{abstract}


appeal to the Tax Court. The Customs Law clearly regulates the mechanism of objection and appeal in article 93 through article 95. Likewise, the affirmation of the application of the customs Law everything related to the completion of customs obligations on imported or exported goods, including filling objections, as stipulated in article 6 of the Customs Law. In principle, the Tax Court Decision is Final and has permanent leegal force, it cannot be cariied out by a public court suit, a state administrative court, orr another judical body. Disputing parties who are dissatiisfied with the Tax Court's decision are still allowed to make other legal remedies in the form of extraordinary legal remedies, namely filling a review of the Tax Courrt's decision to the Supreme Court. This study uses normative juridical research with a positive legal inventory approach. The data sources used in this study are secondary data collection literature. This study uses qualitative analysis with process of deductive thinking. In the variable of Customs and Excise Customs Value Determination. The results of this study explain that the Dispute variable Against the Determination of Customs Value greatly affects the total state revenue.

Keywords: Objection, Appeal, Review

\section{Latar Belakang}

Republik Indonesia sebagai negara hukum menghendaki terwujudnya sistem hukum nasional yang mantap dan mengabdi kepada kepentingan nasional, bersumber pada Pancasila dan Undang-undang Dasar Negara Republik Indonesia Tahun 1945. Akan tetapi, sejak kemerdekaan Undang-undang kepabeanan nasional belum dapat dibentuk sehingga Indische Tarief Wet (Undang-undang Tarif Indonesia) Staatsblad Tahun 1873 Nomor 35, Rechten Ordonnantie (Ordonansi Bea) Staatsblad Tahun 1882 Nomor 240, dan Tarief Ordonnantie (Ordonansi Tarif) Staatsblad Tahun 1910 Nomor 628 masih diberlakukan berdasarkan Pasal II Aturan Peralihan Undang-undang Dasar 1945.

Meskipun terhadap ketiga peraturan perundang-undangan tersebut telah dilakukan perubahan dan penambahan untuk menjawab tuntutan pembangunan nasional, karena perubahan tersebut bersifat partial dan tidak mendasar serta berbeda falsafah yang melatarbelakangi, perubahan dan penambahan tersebut belum dapat memenuhi tuntutan dimaksud sehingga perlu dilakukan pembaruan.

Dalam mewujudkan peraturan perundang-undangan yang berlandaskan Pancasila dan Undang-undang Dasar 1945, yang didalamnya terkandung asas keadilan, menjunjung tinggi hak setiap anggota masyarakat, dan menempatkan Kewajiban Pabean sebagai kewajiban kenegaraan yang mencerminkan peran serta anggota masyarakat dalam menghimpun dana melalui pembayaran Bea Masuk, maka peraturan perundang-undangan kepabeanan ini sebagai bagian dari hukum fiskal harus dapat menjamin perlindungan kepentingan masyarakat, kelancaran arus barang, orang, dan dokumen, penerimaan Bea Masuk yang 
optimal, dan dapat menciptakan iklim usaha yang dapat lebih mendorong laju pembangunan nasional.

Dengan letak geografis Negara Indonesia yang terdiri dari wilayah permukaan bumi meliputi dari 17.504 (tujuh belah ribu lima ratus empat) pulau besar dan pulau kecil, 6.000 (enam ribu) pulau tidak berpenghuni yang terbentang sepanjang 3.977 (tiga ribu Sembilan ratus tujuh puluh tujuh) mil yang terletak di antara Samudra Hindia dan Samudra Pasifik. Jika semua daratannya dijadikan satu maka luas negara Indonesia seluas 1,9 juta mil. ${ }^{1}$ Daerah Pabean adalah wilayah Republik Indonesia yang meliputi wilayah darat, perairan dan ruang udara diatasnya, serta tempat-tempat tertentu di Zona Ekonomi Ekslusif dan landasan kontinen yang didalamnya berlaku Undang-Undang Republik Indonesia Nomor 17 Tahun 2006 tentang Perubahan atas Undang-Undang Republik Indonesia Nomor 10 Tahun 1995 tentang Kepabeanan (Lembar Negara Republik Indonesia Tahun 2006 Nomor 93 dan Tambahan Lembaran Negara Republik Indonesia Nomor 4661). ${ }^{2}$

Mengingat luasnya daerah pabean Indonesia yakni seluas wilayah kedaulatan Negara Indonesia, maka tidak mungkin pemerintah mampu menempatkan semua petugas bead an cukai (custom) di sepanjang garis perbatasan di seluruh wilayah pabean Republik Indonesia untuk mengawasi keluar dan masuknya barang dalam rangka kegiatan ekspor impor. ${ }^{3}$

Direktorat Jenderal Bea dan Cukai dengan kewenangan yang dimilikinya berperan dalam pelaksanaan pembangunan, sebagai unsur pelaksana tugas Departemen Keuangan RI dibidang Kepabeanan dan Cukai sejak ditetapkan Undang-Undang Nomor 10 Tahun 1995 dan dengan adanya perubahan dengan Undang-Undang Nornor 17 Tahun 2006 tentang Kepabeanan. Direktorat Jenderal Bea dan Cukai mendapatkan berbagai masukan dan keinginan dari masyarakat agar proses pelayanan dan/atau modal terhadap kesetaraan hak dan kewajiban antara para importir dan aparat Direktorat Jenderal bea dan Cukai.

Bentuk reward dan punishment ditetapkan secara tegas, bahkan bagi aparat Direktorat Jenderal Bea dan Cukai terlibat dalam pelanggaran dibidang kepabeanan dikenakan sanksi yang lebih berat. Dengan demikian diharapkan agar para pejabat/pegawai Direktorat Jenderal Bea dan Cukai dapat lebih meningkatkan kinerja dan profesionalitasnya, sehingga citra Direktorat Jenderal Bea dan Cukai dimata masyarakat dan dunia menjadi lebih baik Agustus 2018.

${ }^{1}$ Wikipedia “Indonesia”, diakses dari https;//id.wikipedia.org/wiki/Indonesia\#Geografi pada tgl 25

2 Pasal 1 butir 2 Undang - Undang Republik Indonesia Nomor.17 tahun 2006 tentang Perubahan atas Undang - Undang Republik Indonesia Nomor.10 Tahun 1995 tentang Kepabeanan (Lembar Negara Republik Indonesia Tahun 2006 Nomor 93 dan Tambahan Lembaran Negara Republik Indonesia Nomor.4661). Atau disebut UU Perubahaan Kepabeanan.

3 Sunarno,Sistem dan Prosedur Kepabeanan di Bidang Export, (Jakarta;2007) hlm.1. 
semua itu, akan bermuara pada peningkatan dan berkembangnya perekonomian nasional secara umum.

Adapun penilaian terhadap komponen biaya adalah seluruh biaya yang terkait dengan penyelesaian prosedur ekspor impor, seperti biaya dokumen, biaya administratif untuk kepabeanan dan pengawasan teknis, biaya bongkar muat (Terminal Handling Charges). Bank Dunia menilai, negara pemilik sistem kepabenan yang efisien, jaringan transportasi yang baik, dan sedikitnya kebutuhan dokumen akan membuat prosedur ekspor impor makin cepat dan murah sehingga sangat kompetitif secara global.

\section{Permasalahan}

Berdasarkan uraian pada latar diatas, maka rumusan yang akan dibahas adalah :

1. Kedudukan nilai transaksi yang tidak memenuhi persyaratan untuk diterima dan ditetapkan sebagai Nilai Pabean (Studi kasus putusan Put/52674/PP/M.XVIIA/19/2014)

2. Membangun suatu model penerapan hukum terhadap Penetapan Nilai Kepabeanan menurut Undang - Undang Nomor.17 Tahun 2006 tentang Perubahan atas Undang Undang Nomor.10 Tahun 1995 tentang Kepabeanan.

\section{Metode Analisis Data}

Jenis penelitian yang digunakan adalah metode pendekatan yuridis normatif, yaitu penelitian hukum yang dilakukan dengan cara meneliti bahan pustaka atau data sekunder belaka, dapat dinamakan penelitian hukum normatif atau penelitian hukum kepustakaan. Dalam bidang ilmu hukum terutama dikenal penelitian hukum normatif (investarisasi hukum positif, penemuan dasar falsafah dibuatnya hukum positif tersebut, penemuan hukum incroceto untuk menyelesaikan kasus hukum, evaluasi apakah suatu hukum bertentangan dengan hak asasi manusia atau bertentangan dengan dasar falsafah Negara , atau tidak sesuai dengan teori, dan sebagainya

\section{Kedudukan Nilai Transaksi Pabean tidak memenuhi persyaratan untuk diterima dan ditetapkan sebagai Nilai Pabean}

1. Peraturan Menteri Keuangan Nomor. PMK-160/KMK.04/2010 tentang Nilai Pabean Untuk Penghitungan Bea Masuk

Dalam PMK ini diatur tentang hal-hal yang berkaitan dengan persyaratan diterimanya nilai transaksi dan dalam hal apa nilai pabean yang diberitahukan tidak diterima oleh pejabat. 
Salah satu ketentuan penting dalam PMK-160/KMK.04/2010 yang berpotensi besar menimbulkan sengketa adalah pasal 8 (d) yang menyatakan bahwa nilai transaksi tidak digunakan untuk penentuan nilai pabean bilamana pejabat Bea dan Cukai mempunyai alasan berdasarkan bukti nyata atau data yang obyektif dan terukur untuk tidak menerima nilai transaksi yang diberitahukan.

Potensi sengketa sangat mungkin terjadi karena pada PMK ini tidak dijelaskan wujud nyata dari terminologi bukti nyata atau data yang obyektif dan terukur. Muncul pertanyaan apakah database nilai pabean yang disusun oleh DJBC termasuk kategori bukti nyata atau data yang obyektif dan terukur ataukah tidak. Hal ini penting untuk memberikan kepastian hukum baik kepada pejabat Bea dan Cukai maupun kepada importir.

Ketentuan lainya yang diatur pada PMK-160/KMK.04/2010 yang berpotensi besar menimbulkan sengketa adalah uji kewajaran nilai pabean. Perlu diketahui bahwa uji kewajaran nilai pabean tidak diatur dalam Undang-Undang Kepabeanan, dan tidak terdapat secara eksplisit di Agreemet on Implementation of Article VII of GATT. Ketentuan uji kewajaran ini diatur pada pasal 26 dan 27 PMK- 160/KMK.04/2010. Uji kewajaran nilai pabean dilakukan dengan menggunakan DBNP I barang identik. Nilai pabean dianggap wajar bila nilai yang diberitahukan lebih besar, sama dengan atau lebih kecil dari nilai di DBNP I sepanjang tidak lebih dari 5\%. DBNP II barang identik digunakan bilamana data tidak tersedia pada DBNP I Dalam uji kewajaran menggunakan DBNP II, nilai pabean dianggap wajar bila diberitahukan lebih besar atau sama dengan nilai di DBNP II.

Proses selanjutnya bila nilai pabean diragukan karena dianggap tidak wajar adalah permintaan pejabat kepada importir untuk menyerahkan deklarasi nilai pabean (DNP) dengan melampirkan dokumen pendukung. Permintaan DNP hanya dikenakan kepada importir kategori medium risk dan high risk. Bilamana DNP tidak diserahkan atau pejabat meragukan keterangan dalam DNP dan konsultasi yang dilakukan tidak meyakinkan pejabat, maka nilai transaksi yang diberitahukan tidak dapat diterima.

Ketentuan yang ditetapkan dalam peraturan perundang-undangan yeng terkait dengan nilai pabean, yakni Pasal 15 Undang-Undang Nomor 17 Tahun 2006 tentang Perubahan Atas Undang- Undang Nomor 10 Tahun 1995 tentang Kepabeanan jo. Peraturan Menteri Keuangan Nomor: 160/PMK.04/2010 tentang Nilai Pabean Untuk Penghitungan Bea Masuk dan peraturan perundang-undangan terkait lainnya.

\section{Pentingnya Kehadiran Dirjen Bea dan Cukai}

Direktorat Jenderal Bea dan Cukai dengan kewenangan yang dimilikinya berperan 
dalam pelaksanaan pembangunan, sebagai unsur pelaksana tugas Departemen Keuangan RI dibidang Kepabeanan dan Cukai sejak ditetapkan Undang - Undang Nomor 10 Tahun 1995 dan dengan adanya perubahan dengan Undang - Undang Nornor 17 Tahun 2006 tentang Kepabeanan, bahwa Direktorat Jenderal Bea dan Cukai mendapatkan berbagai masukan dan keinginan masyarakat agar proses pelayanan dan dan atau modal terhadap kesetaraan hak dan kewajiban antara para importir dan aparat Direktorat Jenderal bea dan Cukai.

Nilai pabean sesuai kesepakatan WTO yang sering disebut dengan WTO valuation atau GATT Valuation Agreement (GVA), mulai diterapkan di Indonesia sejak disahkannya Undang-Undang Nomor 10 Tahun 1995 tentang Kepabeanan. Implikasi dari digunakannya nilai transaksi adalah nilai pabean yang diberitahukan importer harus diterima aparat pabean, sepanjang memenuhi persyaratan nilai transaksi. Ketentuan ini bagi negara berkembang seperti Indonesia sangat sulit diterapkan mengingat masih masih cukup banyak importir yang beresiko tinggi.

Importir yang tidak setuju atas penetapan tarif dan/atau nilai pabean oleh pihak pabean sehingga mengakibatkan tambah bayar bea masuk dan pajak dalam rangka impor diberi kesempatan oleh undang-undang untuk mengajukan keberatan. Komplain atas penetapan pejabat pabean dalam rangka pemeriksaan pabean tidak dapat dilakukan kepada pihak manapun, kecuali hanya kepada Direktur Jenderal Bea dan Cukai. Hal ini diatur dengan jelas dalam Undang-undang Kepabeanan.

Penetapan SPTNP (Surat Penetapan Tarif dan Nilai Pabean) merupakan koreksi yang dilakukan oleh Pejabat Pabean atas pemberitahuan impor barang yang diajukan oleh importir. Koreksi merupakan hasil dari pemeriksaan pabean termasuk penelitian kebenaran pemberitahuan impor. Walaupun importir sudah merasa mengisi pemberitahuan impor dengan data yang sebenar-benarnya bukan berarti pemberitahuannya sudah benar, khususnya mengenai data harga barang dan penggolongan tarif barang impor. Untuk menghitung bea masuk variabel yang digunakan adalah tarif dan harga barang. Penggolongan tarif barang sudah jelas pedomannya dalam buku tarif (Buku Tarif Kepabeanan Indonesia). Perbedaan tariff yang mungkin terjadi karena perbedaan persepsi penempatan barang dalam pos tarif. Sedangkan harga barang untuk menghitung bea masuk (nilai pabean) harus memenuhi persyaratan nilai pabean, sehingga walaupun data harga yang disampaikan dalam pemberitahuan pabean merupakan data harga yang sebenarnya namun belum tentu harga tersebut memenuhi persyaratan nilai transaksi.

Pengertian keputusan atau penetapan dalam ketentuan perundang - undangan kepabeanan merupakan pemberitahuan, penetapan dan penagihan. Sebagai pemberitauan 
adalah pembatasan mengenai jangka waktu untuk melaksanakan kewajiban melunasi kekurangan pembayaran bea masuk, pajak dalam rangka impor serta sanksi administrasi berupa denda. Pengertian penetapan, dimaksudkan sebagai suatu keputusan tertulis yang dikeluarkan oleh pejabat tata usaha Negara. Dengan predikat sebagai keputusan, sesuai dengan Undang - Undang Kepabaeanan, kepada Wajib Pabean diberikan hak untuk mengajukan upaya administrasi berupa pengurangan, penghapusan, sanksi administrasi atau pembatalan surat penetapan.

Terminologi penetapan sebagai penagihan, merupakan bagian tidak terpisah dari kewajiban pemenuhan pembayaran atau pelunasan atas bea masuk dan pajak dalam rangka impor beserta sanksi adminitrasi, sebagai akibat kurang bayar. Meskipun penagihan termasuk dalam ranah perundang - undangan lain yaitu Undang - Undang Nomor.19 Tahun 1997 Tentang Penagihan Pajak Dengan Surat Paksa sebagaimana telah dirubah dengan Undang- undang Nomor. 19 Tahun 2000, tetapi Undang - undang Kepabeanan memberlakukan seperti diatur dalam Pasal 41 sebagai dasar hukum pelaksaan penagihan bea masuk.

Kepabeanan dan pelabuhan adalah suatu hal yang tidak dapat dipisahkan. Pelabuhan memiliki beberapa pengertian, sebagai berikut :

1. Pengertian Pelabuhan Secara Umum "Pelabuhan adalah suatu tempat (daerah perairan dan daratan) dimana kapal dapat berlabuh dengan aman dan dapat melakukan bongkar / muat barang dan turun / naik penumpang dari / ke kapal.

2. Pengertian Pelabuhan Menurut PP No. 11 tahun 1983, "Pelabuhan adalah daerah tempat berlabuh dan / atau bertambatnya kapal laut untuk menaikkan dan menurunkan penumpang”. Dalam perkembangan selanjutnya, pengertian pelabuhan mencakup pengertian sebagai prasarana dari sistem transportasi.

\section{Fungsi dan Tujuan Bea dan Masuk Impor}

Bea masuk impor selain berfungsi sebagai salah satu pemasukan pendapatan negara, juga bertujuan antara lain :

- Proteksi terhadap industri dalam negeri, tujuan ini menjadi salah satu tujuan terpenting dalam mendasari adanya kebijakan bea masuk impor.

- Pencegahan penyelundupan dari barang - barang impor illegal. Baik itu karena tidak adanya dokumen maupun karena barang tersebut memang tidak diperbolehkan masu seperti narkoba dan lainnya. 
- Perlindungan yang bersifat sementara

- Efisiensi administrasi kepabeanan

Membangun suatu model penerapan hukum terhadap Penetapan Nilai Kepabeanan menurut Undang - Undang Nomor.17 Tahun 2006 tentang Perubahan atas Undang Undang Nomor.10 Tahun 1995 tentang Kepabeanan

\section{Dasar Hukum Nilai Pabeanan}

Pengertian bea masuk menurut Undang - undang Nomor.10 Tahun 1995 tentang Kepabean sebagaimana telah dirubah dengan Undang - undang Nomor.17 Tahun 2006, adalah pungutan Negara berdasarkan undang - undang ini dikenakan terhadap barang yang di impor. Sebagai pungutan atau $d u t$, pengerttian ini berbeda dengan pajak, dalam Undang - undang Ketentuan Umum dan Tata Cara Perpajakan disebutkan "Pajak adalah kontribusi wajib kepada Negara yang terutang oleh orang pribadi atau badan yagn bersifat memakasa berdasarkan undang - undang, dengan tidak mendapatkan imbalan secara langsung dan di gunakan untuk keperluan Negara bagi sebesar-besarnya kemakmuran rakyat.

Ketentuan umum Undang - Undang Nomor.17 Tahun 2006 tentang Perubahan atas Undang - Undang Nomor.10 Tahun 1995 tentang Kepabeanan, Pasal 15, yang menyatakan bahwa Nilai Pabeanan untuk perhitungan bea masuk adalah nilai transaksi dari barang-barang yang di impor. Nilai ini merupakan harga yang sebenarnya dibayar oleh pembeli kepada penjual atas barang yang dijual untuk diekspor ke daerah pabean nilai atau harga dalam transaksi merupakan harga yang sebenarnya atau disepakati dalam kontrak perjanjian.

Sedangkan dasar hukum yang melandasi adanya Bea masuk impor adalah Pasal 12 ayat (1) UU No. 10 Tahun 1995 Tentang Kepabeanan dan dengan memperhatikan Undang-undang No. 7 Tahun 1994 tentang Pengesahan Agreement Establishing the World Trade Organization (Persetujuan Pembentukan Organisasi Perdagangan Dunia). Adapun dalam UU No. 17 Tahun 2006 Tentang Perubahan Undang - Undang No. 10 Tahun 1995 pasal ini tidak dirubah sama sekali.

Hal ini berarti dalam melaksanakan pungutan bea masuk impor, yang menjadi dasar hukum adalah Undang - Undang No. 10 Tahun 1995 Tentang Kepabeanan Pasal 12 ayat (1) dan bukan Undang - Undang No. 17 Tahun 2006 Tentang Perubahan Undang -Undang No. 10 Tahun 1995 Tentang Kepabeanan. Sedangkan pengecualian maupun perubahan atas besaran tarif mengikuti ketentuan yang lain. Baik itu pasal dan ayat selain Pasal 12 ayat (1) maupun atas keputusan dan peraturan dari kementerian keuangan yang mana membawahi direktorat jenderal bea dan cukai. 


\section{Tinjauan Umum Tentang Ekspor Impor}

Dalam era perdagangan international (perdagangan bebas dan persaingan bebas), baik secara bilateral (antara dua Negara), multilateral (antara berbagai Negara), maupun regional (antara beberapa Negara dengan Negara lain), memunculkan perdagangan antar perorangan, perusahaan nasional maupun internasional, untuk melakukan perjanjian jual beli barang atau jasa. Pengertian perdagangan ekpor impor, dapat di artikan sebagai perdagangan bermacam jenis dan kualitas barang yang terjadi antara Negara satu dengan Negara lainnya.

Ekspor diartikan sebagai kegiatan penjualan atau pengiriman barang, jasa atau modal yang berasal dari daerah pabean keluar daerah pabean melalui perjanjian atau tidak, yang dilakukan oleh orang, badan hukum atau Negara, sesuai dengan peraturan yang berlaku.

Impor diartikan memasukan barang, jasa atau modal yang berasal dari luar daerah pabean kedalam daerah pabean, dengan tujuan untuk dipakai, dimiliki, dialihkan atau dijual dengan mendapatkan manfaat atau keuntungan atas barang, jasa.

Konsep Impor berasal dari adanya kegiatan dalam perdagangan International, terkait dengan adanya jual beli barang yang dilakukan lintas Negara. Impor merupakan kegiatan memasukan barang ke dalam daerah pabean baik yang dilakukan oleh orang pribadi maupun badan hukumyang dibawa oleh sarana pengangkut telah melintasi batas Negara dan kepadanya diwajibkan memenuhi kewajiban pabean sepertti, pembayaran bea masuk dan pajak dalam rangka impor yang terutang.

\section{Analisis Putusan Terhadap Sengketa Penetapan Nilai Pabean Dalam Ekspor Impor}

\section{Kasus Posisi}

Bahwa benar pada tanggal 3 Januari 2013 pihak Impotir Shenzen Yitong Baoye Trading CO.LTD menerima surat keputusan dari Dirjen Bea dan Cukai dengan Nomor Keputusan KEP-13/WBC.10/2013 atas penetapan Nilai Pabean atas Impor 34 jenis barang.

Bahwa menurut Impotir Shenzen Yitong Baoye Trading CO.LTD Import atas 34 jenis brang sesuai lembaran PIB ( Pemberitahuan Impor Barang ) sesuai dengan Letter of Credit Nomor: 202LC20572 tanggal 27 September 2012 dan Commercial Invoice Nomor: 20121005 tanggal 5 Oktober 2012.

\section{Sengketa Penetapan Nilai Pabean}


Sengketa kepabeanan adalah ketidak sesuai pendapat atau penafsiran ketentuan perundang - undangan, penghitungan dan penetapan jumlah bea masuk, cukai dan pajak dalam rangka impor yang seharusnya dibayar, antara Pengguna jasa Kepabeanan dan Pejabat Pabean.

Penyelesaian sengketa ini dapat dilakukan melalui upaya administrasi dan upaya hukum oleh Wajib Pabean dengan memenuhi persyaratan yang telah ditentukan oleh perundang undangan Kepabean yang berlaku.

Undang - Undang Kepabeanan dan undang - undang cukai menganut Asas Proposionalitas atau asas kesebandingan atau proposionaliteit beginsel. Di dalam asas tersebut terkandung pengertian yang terkait dengan denda yaitu :

"Berat atau ringannya satu sanksi administrasi, ditentukan oleh besar atau kecilnya kerugian yang diderita Negara menurut frekuensi pelanggaran yang dilakukan oleh orang atau badan hukum dalam suatu kurun waktu tertentu".

Dalam penegakan hukum kepabeanan, pengenaan sanksi atas pelanggaran atau penyimpangan yang dilakukan oleh pengguna jasa diatur tersendiri Sanksi Administrasi merupakan sanksi berupa denda yang dikenakan terhadap setiap orang yang melakukan pelanggaran administrasi yang secara nyata telah diatur dalam Undang - Undang. Sebagai peraturan pelaksana mengenai sanksi administrasi, diatur dalam peraturan Menteri Keuangan Nomor 78/PMK.04/2008 Tentang Petunjuk pelaksanaan pemberlakuan sanksi administrasi berupa denda dibidang kepabeanan. Pejabat bea dan cukai dapat menerapkan tarif atas barang impor yang diberitahukan dalam pemberitahuan pabean impor. Kekurangan pembayaran bea masuk sebagai akibat penetapan dan atau nilai pabean, diruangkan dalam bentuk Surat Penetapan Tarif dan atau Nilai Pabean (SPTNP) yang berfungsi sebagai penetapan, pemberitahuan dan penagihan.

Kepabeanan kita menganut prinsip bahwa dasarnya semua pemilik barang dapat menyelesaikan kewajiban pabeannya. Namun tidak semua pemilik barang mengetahui, mengerti dan memahami ketentuan tatalaksana kepabean, atau karena tidak mampu mengahadapi kerumitan birokrasi, dapat memberikan kuasa khusus kepada PPJK. Untuk mendapatkan Nomor Pokok Pengusaha Pengurusan Jasa Kepabeanan wajib melakukan regristrasi melalui media elektronik kepada Direktur Jendral atau Pejabat yang ditunjuknya.

Dalam rangka melaksanakan ketentuan Pasal 17A Peraturan Menteri Keuangan Nomor 122/PMK.04/2011 tentang Perubahan Kedua atas Peraturan Menteri Keuangan Nomor 51/PMK.04/2008 Tentang Cara Penetapan Tarif, Nilai Pabean, dan Sanksi Administrasi dan 
Peraturan Dirjen Bea dan Cukai Nomor 45/BC/2011 diatur mengenai penelitian ulang, yaitu penelitian kembali atas Tarif dan /atau Nilai Pabean.

Dalam hal penetapan kembali berakibat kekurangan pembayaran bea masuk dan/ atau pajak dalam rangka impor terkait adanya kesalahan nilai transaksi yang diberitahukan, importir wajib membayar kekurangan bea masuk dan/ atau pajak dalam rangka impor, dan Sanksi Administrasi berupa Denda paling sedikit 100\% (seratus persen) dari bea masuk yang kurang bayar akan diterbitkan Surat Penetapan Kembali Tarif dan Nilai Pabean atau SPKTNP.

Pejabat pabean oleh Undang -Undang diberikan kewenangan untuk melakukan penelitian ulang atas dokumen yang sudah selesai. Berdasar Pasal 17 Undang - Undang Kepabeanan. Pemeriksaan ulang dapat dilaksanakan oleh pejabat Bea dan Cukai dalam hal ditemukan perbedaan antara pemeriksaan ulang dan pemeriksaan terdahulu, Pejabat bea dan Cukai menerbitkan Informasi Nilai Pabean (INP) yang dikirim kepada importir melalui media elektronik, kuasanya atau pos kilat selambat - lambatnya pada hari kerja berikutnya. Informasi ini diperlukan untuk mengetahui pertama, apakah barang dapat dimasukan kategori sebagai subjek penjualan. Kedua, apakah terdapat hubungan antara ekportir dan importir yang mempengaruhi harga. Peraturan Dirjen Bea dan Cukai Nomor 45/BC/2011 Tentang Petunjuk Pelaksanaan Penelitian Ulang/kembali atas Tarif dan Nilai Pabean.

\section{Simpulan}

Sengketa atas penetapan nilai tarif pabean atas biaya ekspor -impor yang tidak Sesuai dengan nilai yang di beritahukan oleh Dirjen Bea dan Cukai maka Pemilik barang dapat mengajukan banding atas penetapan nilai tarif yang Ditetapakan oleh Dirjen Bea dan Cukai sesuai yang diatur Undang - Undang Nomor. 17 tahun 2006, dan kedudukan nilai transaksi yang tidak memenuhi Persyaratan untuk diterima atau ditetapkan sebagai nilai pabaean, harus Mengikuti mekanisme yang berlaku, Dirjen Bea dan Cukai sebagai institusi yang diberi tanggung jawab menghimpun bea masuk berkewajiban mengoptimalkan penerimaan Negara.

Mengingat begitu seriusnya permasalahan nilai pabean, hendaknya Direktur Jenderal Bea dan Cukai membuat struktur yang berkosentrasi penuh pada penyiapan perangkat dan data nilai pabean baik pada Kantor Pusat maupun di Kantor Wilayah dan Kantor Pelayanan Utama. Sesuai dengan Peraturan Menteri Keuangan Nomor 100/PMK.01/2008 tentang Organisasi dan Tata Kerja Departemen Keuangan, saat ini telah ada Sub Direktorat Nilai 
Pabean di Kantor Pusat Direktur Jenderal Bea dan Cukai yang bertugas melaksanakan penyiapan penyusunan kebijakan, standardisasi dan bimbingan teknis, evaluasi dan pelaksanaan di bidang nilai pabean dan data harga. Salah satu output dari Sub Direktorat Nilai Pabean adalah Database Nilai Pabean (DBNP) I yang digunakan untuk uji kewajaran nilai pabean dan dapat digunakan untuk penetapan nilai pabean. Sesuai dengan Peraturan Direktur Jenderal Bea dan Cukai Nomor 40/BC/2010 tentang Database Nilai Pabean, DBNP I disusun oleh Kantor Pusat dan harus dilakukan pemutakhiran secara periodik sekurangkurangnya 1 (satu) kali dalam 1 (satu) bulan.

Selain perbaikan dan penyederhaan tatacara penelitian nilai pabean, salah satu critical point dalam peraturan Menteri Keuangan ini adalah adanya uji kewajaran nilai transaksi dalam proses penetapan nilai pabean oleh pejabat. Uji kewajaran yang dapat bermuara pada ditolaknya nilai transaksi diperkuat oleh ketentuan pasal 8 (d) peraturan ini yang menyebutkan bahwa "nilai transaksi tidak digunakan dalam hal pejabat Bea dan Cukai mempunyai alasan berdasarkan bukti nyata atau data yang obyektif dan terukur untuk tidak menerima nilai transaksi sebagai nilai pabean". Mekanisme penetapan nilai pabean seperti ini bila kita kaji lebih lanjut sebenarnya tidak memiliki landasan yang kuat pada UndangUndang Kepabeanan. Dalam kasus ini , Menurut Penulis bahwa pertimbangan Putusan Mahkamah Agung yang memutus perkara Shenzen Yitong Baoye Trading CO.LTD. sangat cermat dan tepat dan sudah jelas bahwa, Nilai Pabean sebesar CIF USD 17.812,18 adalah harga yang sebenarnya atau yang seharusnya dibayar. Maka terhadap Keputusan Direktur Jenderal Bea dan Cukai Nomor :KEP-13/WBC.10/2013 tanggal 3 Januari 2013 tentang Penetapan atas keberatan terhadap SPTNP Nomor :SPTNP007229/NOTUL/WBC.10/KPP.01/2012 tanggal 8 November 2012, sehingga Nilai Pabean atas impor 34 jenis barang sesuai lembar lanjutan PIB Negara asal China sesuai dengan yang diberitahukan dalam PIB Nomor:105761 tanggal 31 Oktober 2012 sebesar CIF USD 17.812,18, adalah sudah tepat dan benar, berdasarkan Pasal 8 Peraturan Menteri Keuangan Indonesia Nomor: 160/PMK.04/2010 tanggal 1 September 2010 tentang Nilai Pabean untuk Penghitungan Bea Masuk. Nilai Transaksi sebagaimana dimaksud dalam Pasal 2 ayat (1) tidak digunakan untuk menentukan Nilai Pabean. Berdasarkan Pasal 15 ayat (1) Undang Undang Nomor 10 tahun 1995 tentang Kepabeanan sebagaimana telah diubah dengan Undang - Undang Nomor.17 tahun 2006 menyebutkan Nilai Pabean untuk penghitungan Bea Masuk adalah nilai transaksi dari barang yang bersangkutan. Karena Indonesia menganut civil law, sangat mengutamakan adanya aturan tertulis.

\section{Saran}


Dewan Perwakilan Rakyat perlu meningkatkan pengawasan terhadap Direktur Jenderal Bea dan Cukai agar dapat mengelola dan mengoptimalkan Pemasukan bagi Negara.

Direktur Jenderal Bea dan Cukai perlu melakukan upaya - upaya preventif untuk meminimalisasi terjadinya keliru dalam penetapan nilai pabean.

Direktur Jenderal Bea dan Cukai perlu secara sungguh-sungguh melakukan perbaikan, baik dalam aspek internal maupun aspek eksternal. Aspek internal berkaitan dengan dukungan institusi dan penyiapan pejabat yang profesional, sedangkan aspek eksternal berhubungan dengan bimbingan kepatuhan dan law enforcement.

Dalam penyelesaian sengketa banding penetapan nilai pabean melalui Pasal 93,93 A dan 94 Undang - Undang Nomor.17 tahun 2006 tentang Kepabaeanan.

Adanya beberapa peraturan yang bersifat multitafsir dan tidak jelas. Peraturan-peraturan ini menjadi sulit untuk dilaksanakan sehingga pada akhirnya dapat menimbulkan sengketa penetapan nilai pabean. Oleh karena itu maka Direktur Jenderal Bea dan Cukai memperbaiki ketentuan yang dapat menimbulkan ketidakpastian hukum di masa yang akan datang.

Demi kepastian hukum dan untuk menghindari banyaknya sengketa atas penetapan nilai pabean, maka sebaliknya terdapat ketentuan yang dengan tegas menyatakan pihak yang tidak puas atas putusan Pengadilan Pajak dimungkinkan untuk melakukan upaya hukum lain berupa upaya hukum luar biasa setelah adanya putusan hukum yang berkekuatan hukum tetap, sebagaimana dalam Pasal 77 Undang - Undang Nomor : 14 tahun 2002 tentang Pengadilan Pajak.

\section{Daftar Referensi}

Adi, Rianto. “Aspek Hukum dalam Penelitian Hukum”, Jakarta; Yayasan Putaka Obor. 2015. Adi, Rianto. “Metodologi Penelitian Sosial dan Hukum”. Jakarta; Granit. 2010.

Admosudirjo, Prajudi. “Dasar - Dasar Ilmu Administrasi”. Jakarta; Gahlia Indonesia Asshiddiqie, Jimly. "Teori Hans Kelsen Tentang Hukum” Jakarta; Konstitusi Press. 2104. Brotodiharjo Santoso, R. "Pengantar Ilmu Hukum Pajak". Bandung; PT.Refika Aditama. 2003.

Fuady, Munir. "Doktrin-Doktrin Modern dalam Corporate Law dan Eksistensinya dalam Hukum Indonesia", Jakarta; PT.CITRA ADTYA BAKTI. 2014.

Jamilah, Fitrotin. "Strategi Penyelesaian Sengketa Bisnis", Yogyakarta; PUSTAKA YUSTISIA. 2014.

Kartika Sari, Elsi, “Hukum dalam Ekonomi”, Jakarta;PT. Gramedia Widiasarana Indonesia. 2008. 
Krugman, Paul.R. "Ekonomi Internasional Teori dan Kebijakan”. Jakarta; PT.Indek. 2004.

Mertokusumo, Sudikno. “Mengenal Hukum”. Yogyakarta; Liberty. 1988.

M.S,Amir. "Seluk Beluk dan Tehnik Perdagangan Luar Negeri”, Suatu Penuntun IMPOR \& EKSPOR. Jakarta; PT.Pustaka Binaman Pressindo. 1993.

Purwito, Ali. "Ekspor, Impor, Sistem Harmonisasi, Nilai Pabean dan Pajak dalam Kepabeanan”. Jakarta; Mitra Wacana Media. 2015.

Raharjo, Satjipto. "Hukum Progresif Sebuah Sintesa Hukum Indonesia'. Yogyakarta; Genta Publishing. 2009.

Renaldy, Eddie. "Istilah Perdagangan Internasional". Jakarta; PT.RajaGrafindo Persada. 2000.

Rusianto, Agus. "Tindak Pidana dan Pertanggung jawaban Pidana”, Jakarta; PT.Fajar Interpratama Mandiri. 2016.

Soekanto, Soerjono. "Penelitian Hukum Normatif Suatu Tinjauan Singkat" Jakarta; PT. RAJAGRAFINDO PERSADA. 2015.

Soemitro, Rochmat. “Asas dan Dasar Perpajakan” Bandung; PT.Refika Aditama. 2010.

Sukinto, Yudi Wibowo. "Tindak Pidana Penyelundupan Di Indonesia". Jakarta; Sinar Grafika. 2015.

Surie, H.G. “'Іти Admisitrasi Negara”. Jakarta; PT.Gramedia. 1987.

Susilo, Andi. "Panduan Pintar Ekspor Impor". Jakarta; Trans Media. 2013

Sutedi, Adrian.” Hukum Ekspor Impor". Jakarta; Raih Asa Sukses. 2014.

Widjajati, Erna. "Pembaharuan Hukum Pajak dan Kebijakan Pajak Di Indonesia”. Ciputat Tanggerang Selatan; CV. Wafi Media Tama. 2016.

Widjajati, Erna. "Hukum Perlindungan Konsumen di Indonesia". Ciputat Tanggerang Selatan; CV.Wafi Media Tama. 2016.

Widjajati, Erna. "Pengantar Ilmu Hukum”. Jakarta; Jalur.2011.

Widjaja Gunawan dan Ahmad Yani. “Transaksi Bisnis International Ekspor Impor”. Jakarta; RajaGrafindo Persada. 2010.

\section{Peraturan Perundang - Undangan}

Undang-Undang Nomor 20 Tahun 2014 tentang Standarisasi dan Penilaian Kesesuaian. Tambahan Lembaran Negara Republik Indonesia Nomor 5584.

Peraturan Pemerintah No.34 Tahun 2011 Tentang Tindakan Antidumping, Tindakan Imbalan, dan Tindakan Pengamanan Perdagangan.

Peraturan Menteri Perdagangan No. 54/M-DAG/PER/10/2009 Tahun 2009 tentang Ketentuan Umum di Bidang Impor. Berita Negara Republik Indonesia Tahun 2009 Nomor 524.

Peraturan Menteri Perdagangan Nomor 13/M-DAG/PER/3/2012 tentang Ketentuan Umum di bidang Ekspor. Berita Negara Republik Indonesia Tahun 2012 Nomor 395.

\section{Internet}

Wikipedia "Indonesia", diakses dari https;//id.wikipedia.org/wiki/Indonesia\#Geografi pada tgl 25 Agustus 2018. 
http://sejarah.kompasiana.com/2013/05/13/sejarah-bea-dan-cukai-di-indonesia559578.html.

diakses tanggal 6 Nopember 2018

http://www.sui.co.id/index.php.artikel/lastest-news/120-sejarah-kepabeanan-indonesia. di akses tanggal 5 Nopember 2018

http://www.google.co.id/search?q=akibat+sengketa+dan+banding+nilai+kepabeanan\&oq= akibat+sengketa=akibat+sengketa+dan+banding\&aqs=cheome..69i57.5040j0j7\&cli ent=ms-android-asus-tpin\&sourceid=chrome-mobile\&ieUFT-8_diakses tanggal 13 Nopember 2018. 